\section{ekf}

VYSOKÁ ŠKOLA BÁŇSKÁ OSTRAVA EKONOMICKÁ FAKULTA.

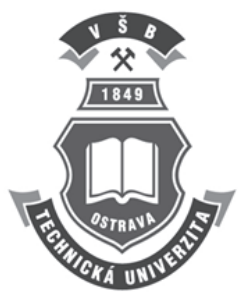

\title{
Impact of motivation principles on employee turnover
}

\author{
Lucie VNOUČKOVÁ $\mathrm{a}^{*}$, Hana KLUPÁKOVÁ \\ ${ }^{a}$ Department of Management, University of Economics and Management, Nárožni 2600/9a, Prague 5, 158 00, Czech Repub- \\ lic. \\ ${ }^{\mathrm{b}}$ Department of Management, Faculty of Economics and Management, Czech University of Life Sciences in Prague, \\ Kamýcká 129, Prague 6, 165 00, Czech Republic.
}

\begin{abstract}
The article focuses on the analysis of motivation principles in human resource management and their further verification by factor analysis. The objective is to identify the main motivation principles and their impacts on employee turnover as well as formulate suggested practices to eliminate the negative impact of employee disaffection and turnover. The identification of motivation principles is based on a content analysis of professional and scientific publications aimed at motivation. The results and conclusions of this study were consequently verified by a quantitative survey, the data of which were statistically processed. As a suitable statistical analysis to assess the data from the survey, a factor analysis was chosen. The data for the factor analysis were collected and analysed based on two quantitative surveys focused on the causes of employee turnover. The results of both analyses proved and verified identical principles of employee management that affect job satisfaction and the decisions of employees to stay or leave their current job positions.
\end{abstract}

\section{Keywords}

Employee, human resource management, management, motivation, principles, turnover.

JEL Classification: J24, J63, J32, J53

\footnotetext{
*lucie.vnouckova@vsem.cz (corresponding author)

This contribution is a follow-up to the research project financed by the University of Economics and Management and prepared with the support of the research project the Internal Grant Agency (IGA) of the Czech Live Sciences University in Prague, registration number 20131011.
} 


\title{
Impact of motivation principles on employee turnover
}

\author{
Lucie VNOUČKOVÁ, Hana KLUPÁKOVÁ
}

\section{Introduction}

Employee turnover is the level of movement of employees inside and outside the organisation (Reiß, 2008). Turnover has both positive and negative aspects; however, it is in the interests of organisations to eliminate the negative impacts and the excessive (negative) level of turnover that threatens knowledge continuity (Branham, 2005; Ertl, 2005; Reiß, 2008; Zahorsky, 2010). Excessive turnover causes an undue burden for a company's budget and human resources, i.e. time dedicated to employee recruiting, advertisements, interviews, initial training, supervision, motivation, evaluation, adaptation to the new job, mentoring, coaching, substitution while the position is vacant and so on (Armstrong, 2009; Bowes, 2010; Reiß, 2008).

Motivation is the main tool to eliminate the negative employee turnover rate inside organisations; this is the backbone of human resource management. The lack of adequate human behaviour motivation will lead to a lack of clear goals and problems with fulfilment as well as a lack of organisational efficiency; further, it is not possible to expect employees to stay in the organisation. The ability of managers to motivate their subordinates comprises the soft skills of human resource management, which is now a dominant trend in global management (Stýblo, 2008). In the past few years, the tasks and functions of the human resource department have moved to line managers and supervisors. Nowadays, the manager is supposed to lead, manage, guide, support and develop his/her subordinates and colleagues. Because the importance of positive work motivation is on the rise, human resource management is focused on the definition of the motivation role and its significance.

The aim of the article is therefore based on the identification of motivation principles that describe this problematic phenomenon inside human resource management in organisations together with the formulation of suggested practices to eliminate the negative impact of employee disaffection and turnover.

The article firstly presents the theoretical background and then the aim and methodology of both researches and analyses. The results firstly present the outputs of the content analysis and the resulting motivation principles. Secondly, the outputs of the factor analysis are presented as a comparison to these principles. Thirdly, the discussion compares all results and presents the congruence of the theoretical and practical results. The conclusion summarises the main outcomes and suggest recommendations.

\section{Theoretical Background}

The motivation role is part of the managerial role. The most frequently cited authors in this area are Mintzberg (2006) and Šuleř (2008). The comparison of both authors shows that their approaches are quite different. This arises from the role definition; Mintzberg (2006) defines managerial roles on the basis of managers' activities, while Šuleř's (2008) definition is based on managers' functions. Šuleř's (2008) concept can be considered to be less detailed because it defines only five roles versus the 10 roles defined by Mintzberg (2006). The deeper analysis shows that managerial roles according to Šuleř (2008) are in fact groups of roles. Šuleř (2008) and Mintzberg (2006) define interpersonal, decision and informational roles (group roles). Each group is quite similar. Šuleř (2008) defines a group of motivational and organisational roles compared with Mintzberg (2006). Mintzberg (2006) includes a motivation role in the interpersonal role.

Šuleř (2008) considers his motivation role to be crucial, because it pervades the other roles. The lack of motivation leads to a rise in outstanding tasks, a reluctance to look for efficient work or employee turnover.

The operationalisation of various motivation forms is an essential condition for fulfilling managerial tasks. The motivation role also includes the engagement of subordinates, i.e. to help the individual behave according to the organisation's rules and standards as well as delegation, coaching, mentoring and performance evaluation (Šuleř, 2008). Managers encourage a workplace culture that supports staff in the required time and direction as a part of his motivation role ( $\mathrm{La}$ Brosse, 2010). Managers use all opportunities to encourage and recognise subordinates as often as possible as well as for little success.

Without an adequate level of motivated behaviour, peoples' actions goals cannot be set up, their fulfil- 
ment and sufficient performance cannot be achieved (Stýblo, 2008). The role of the manager is to keep subordinates activated. The second group of authors including Daigeler (2008) and Niermeyer and Seyffert (2007) cites that current leadership states that the motivation of subordinates is one of the most important managerial tasks. Managers may motivate only in limited dimensions, because the basic motives lie hidden within the subordinate. If a manager stimulates subordinates, the system of stimulus can take the eye off the job description (Daigeler, 2008). According to Niermeyer and Seyffert (2007), a human personality, which is derived from general achievement motivations as well as specific motivations, is slowly influenced by other people. It is thus necessary to pay adequate attention to subordinates despite the difficulty of defining internal motives. Although it would not influence the desired direction, if the manager does not treat subordinates with respect, if he/she does not appreciate their contribution and if he/she does not communicate with them, subordinates will not be satisfied (Plamínek, 2010). The more subordinates lose motivation and their performance decreases, the more physical problems, absenteeism and turnover arise (Crainer, 2004).

La Brosse (2010) states that it is easy to become cynical about the motivation of employees. Their experience can often be called Faux Inspiration, while the organisation presents motivational slogans, statements and principles, but it does not match harmony with the mood of subordinates, the organisation and managers' actions. The same opinion is offered by Niermeyer and Seyffert (2007), who state that motivational speeches do not work at all.

Bělohlávek (2008), Jenkins (2009) and Ramlall (2004) describe the causes of turnover as disharmony with internal motivation. If a need at a higher level of Maslow's pyramid of needs is not satisfied, an individual aims at satisfying a need at a lower hierarchical level. The most common case is that an employee's unfulfilled expectation in the area of self-development translates into the development of relationship needs (Bělohlávek, 2008; Mikuláštík, 2007). Should these be unsatisfactory as well, an employee leaves his/her job (unless conditions are changed).

According to the study by Hackman and Oldham (1980) that concentrates on employees of educational institutions and scientists, six major factors determine turnover. These factors include the level of compensation and benefits, promotion and development, meaningfulness of work, a superior's style of management, relationships with colleagues and work safety. Pass (2005) in Anderson (2009) mentions the 3R system (Recognition, Respect, Relationships) as the main reason for employee satisfaction. Anderson (2009),
Branham (2005) and Katcher and Snyder (2007) extend this by adding remuneration, a suitable culture in the workplace and security (and safety) at work. Ramlall (2004) divides the motivational factors leading to employee satisfaction in their work position into satisfying basic motivational needs according to Maslow (1943), i.e. equal treatment, fulfilment of expectations and workplace concept. The outcome of the studies was a low correlation between dissatisfaction in the workplace leading to turnover and the level of compensation. On the contrary, organisations were recommended to concentrate on the improvement of employee qualifications, enhancement of competences and clear specification of the meaning of the content of the given position.

If the basic working conditions expected by an employee are not met, the employee becomes frustrated (Deiblová, 2005; Kocianová, 2010; Bělohlávek, 2008). Leaving a job can be considered to be an extreme case of a stressful situation and an employee's long-term frustration (Kolman, 2003; Linhart, 2003).

\section{Objective and Methodology}

The present paper verifies the impact of motivation principles on employee turnover. The analyses used for verification were the content analysis of scientific publications and factor analysis.

Publications focused on motivation were analysed using keywords to create the motivation principles most commonly used in the literature. The results of the content analysis were then compared with the output of the factor analysis that focused on the detection of reasons for employee turnover. The results of both analyses permit the generalisation of outputs to further use in praxis.

The first part of the study used a content analysis based on the review of the keywords in professional publications and scientific articles. To achieve partial goals, practical principles and strategies in books in the Czech market were compared. Older publications in book form were chosen for the comparison of the collected information because the most current authors follow the findings made by previous authors. The keywords for the content analysis of the literature were motivation, manager, managerial role and motivation role. Thereafter, a comparison of authors' views was made; some passages were designed as a mutual complementation of the opinions of several authors. If consensus between authors was found, the most current authors were chosen as the base. The practical principles and principles of implementation of the motivation role were selected after defining the role of motivational content and its practical use. The principles were selected on the basis of the keywords: 
motivation principles, motivation rules and motivation propositions. These keywords were compared with the motivation principles contained in books in the Czech market and online databases of articles to ensure and testify ability.

Consequently, the content analysis was performed. Principles were excluded from the analysis when they were too general (fewer than half of the principles related to motivation) and older than three years (except the books read in the original language). Each principle was evaluated by the criteria of the recency, novelty, number of principles, compliance with the motivation role of Šuleř (2008) and guidance. A scale was assigned, where five points were the best. A detailed description of the evaluation is shown in Table 1.

The motivation principle that received the highest score in the summary was selected as the basis for the creation of the keywords. Other principles were analysed after the creation of these keywords and the keywords were assigned afterwards. The keywords were then compared for each author. Keywords that were mentioned by three or more authors were chosen for the recommendations. The principles were drawn from these keywords according to the theoretical literature.

The data for the evaluation of reasons for employees' leaving their jobs were collected in two successive quantitative surveys by means of two questionnaires. Both questionnaires were completed by 100 employees each (different respondents were chosen for the first and second questionnaires) who had already left their jobs. The method used for the collection of data in the first survey was an electronic questionnaire that automatically recorded and pre-categorised respondents' answers. The second (control) questionnaire was based on the CATI method (computer-assisted telephone interviewing). The selection of a representative sample of employees across sectors was carried out by a random selection of telephone numbers, which incorporates the advantages of multilevel random selection (Disman, 2008). The sample was selected solely for the purposes of the survey and it included employees in the age category from 20 to 50 who had left their jobs in the course of the past 12 months. Following an introduction, respondents were included in the survey provided they had satisfied the predefined conditions.

Their answers were categorised according to the identification questions that formed the first part of the questionnaire. In the first survey, measurement was based on closed questions with one or several possible answer(s) that had been selected based on the study of the literature, documents and other related surveys carried out by the following authors: Branham (2005),
Hackman and Oldham (1980), Meyer and Allen (1991) and Katcher and Snyder (2007). In the second survey, a semantic differential was applied that permitted the identification of nuances in respondents' attitudes through the questionnaire. Respondents' reactions to target statements and their attitudes to the given matter were restricted by offering a set of several statements (Hayes, 1998). The extremes of the seven-point scale represented the bipolar concepts of the evaluation dimension. Using a scale of 1 to 7, respondents expressed their inclination towards one of the preset extreme statements or, provided it was not possible to favour either side, selected a median, neutral value (the median value was characterised by number 4 ). The scale permitted not only the specification of respondents' attitudes, but also their intensity. The analysis was carried out using the Microsoft Excel 2007, SAS and SPSS programmes. The conclusiveness of the outputs and relationships obtained were supported by the tools of descriptive statistics; for testing the results, the analysis of correlation and factor analysis were used to review the outcomes.

The surveys did not include a question about the sex of the respondent because the $\chi 2$ test indicated that there is no dependence between sex and reasons to leave the organisation. Further, the $\chi^{2}$ test did not indicate any dependence between the sexes of respondents, while sector does not affect causes of employee turnover.

\section{Results}

This section firstly introduces the results of the content analysis and presents the showed keywords and motivation principles. Secondly, the factor analysis focused on employee disaffection (demotivation) is presented as a way to validate the outcomes of the content analysis. The results below show that a lack of motivation principles leads to employee dissatisfaction and disaffection and may cause employee turnover.

\subsection{Content analysis of motivation principles, rules and axioms}

Based on the content analysis, 13 motivation principles were found. The rules and principles were evaluated according to the predefined criteria. Principles were excluded from the content analysis when they were too general, i.e. at least half of the principles/rules were not related to motivation or were older than three years (except for books read in the original language). Motivation principles were selected (by three authors), strategies (by one author) and rules (by two authors).

All authors were foreigners and their principles were published in scientific journals or books specifically aimed at motivation. The principles were read in English. The shortest motivation principle contained 4 
points (Del Vecchio and Wagner, 2011) and the longest contained 12 points (Vaitkuviené et al., 2010). All principles, rules and strategies consisted of simple sentences. The point evaluation of individual authors provided the following results, see Table 2 .

The principles were divided into two parts after counting the points. Deci and Ryan (2008), Wong-onWing et al. (2010) and La Brosse (2010) received a balanced score for each criterion, while Vaitkuviené et al. (2010), who received fewer points for novelty, occupied the upper part of the assessment (15-17 points). The remaining authors, Hansen et al. (2003), Del Vecchio and Wagner (2011) and Gordon (2010), had 10-12 points. The fewest points were awarded for guidance ( 2 points) and number of principles (2-3 points). Surprisingly, all authors received relatively high points for the criteria of compliance with a motivation role; the only exception was Gordon (2010).

Overall, Wong-on-Wing et al. (2010) received the most points with their basic principles of employee motivation. Ten keywords were defined by Wong-onWing et al. (2010). The comparison of keywords showed that Deci and Ryan (2008) had different keywords to Wong-on-Wing et al. (2010), see Table 3. At least two similar keywords were found for the other authors. Five authors had the same keyword - care for employees. Also significant was creating and sharing of goals, tasks and strategies (four authors).

Table 1 Description of the evaluation of motivation principles

\begin{tabular}{|l|c|c|c|l|}
\hline Points & Recency & $\begin{array}{c}\text { Number of } \\
\text { principles }\end{array}$ & $\begin{array}{c}\text { Compliance with } \\
\text { motivation role }\end{array}$ & Guidance \\
\hline 5 & 2011 & more than 10 & $81-100 \%$ of principles & It is exactly described what a manager should do. \\
\hline 4 & 2010 & $8-9$ & $61-80 \%$ & Manager knows what to do if he/she has experience. \\
\hline 3 & 2009 & $6-7$ & $41-60 \%$ & Manager knows what to do if he/she reads the literature. \\
\hline 2 & 2008 & $4-5$ & $21-40 \%$ & General declaration. \\
\hline 1 & 2007 & less than 3 & $0-20 \%$ & Manager does not know what to do. \\
\hline
\end{tabular}

Table 2 Evaluation of principles

\begin{tabular}{|l|c|c|c|c|c|}
\hline Authors & Novelty & $\begin{array}{c}\text { Number of } \\
\text { principles }\end{array}$ & $\begin{array}{c}\text { Compliance with } \\
\text { motivational role }\end{array}$ & Guidance & Sum \\
\hline Deci and Ryan (2008) & 4 & 4 & 4 & 4 & 16 \\
\hline Vaitkuviené et al. (2010) & 2 & 5 & 4 & 4 & 15 \\
\hline Hansen et al. (2003) & 1 & 2 & 5 & 2 & 10 \\
\hline Del Vecchio and Wagner (2011) & 2 & 2 & 5 & 4 & 17 \\
\hline Wong-on-Wing et al. (2010) & 4 & 4 & 3 & 2 & 12 \\
\hline Gordon (2010) & 4 & 3 & 5 & 3 & 16 \\
\hline La Brosse (2010) & 4 & 4 & 5 & & 2 \\
\hline
\end{tabular}

Note: The numbers are the number of keywords by Wong-on-Wing et al. (2010), which were chosen as the basic keywords for the comparison.

Table 3 Comparison of the keywords

\begin{tabular}{|l|c|c|c|c|c|c|}
\hline Principles of employee motivation & $\begin{array}{c}\text { Deci and } \\
\text { Ryan }\end{array}$ & $\begin{array}{c}\text { Vaitkuviené } \\
\text { et al. }\end{array}$ & Hansen et al. & $\begin{array}{c}\text { Del Vecchio } \\
\text { and Wagner }\end{array}$ & Gordon & La Brosse \\
\hline Positive, inspiring leader & & & & & & $x$ \\
\hline Creating, sharing goals, tasks\&strat. & & $x$ & $x$ & & & \\
\hline Performance measuring\&evaluation & & & & & & \\
\hline Feedback & & $x$ & & & & \\
\hline Link between performance\&reward & & & & $x$ & & $x$ \\
\hline Praise, recognition, appreciation & & & & & \\
\hline Critique & & & & & $x$ & $x$ \\
\hline Open communication & & $x$ & $x$ & & $x$ & $x$ \\
\hline Care for employees & & & & & $x$ \\
\hline Presenting of achievements & & & & & $x$ \\
\hline
\end{tabular}

Note: Where the $x$ is stated as a match in keywords. 
For other unclassified rules, principles and policies, keywords were created. Eleven other keywords were defined, nine of them were found only from one author. A positive, inspiring leader was found to be a very important keyword (matched by five authors).

Twenty-one keywords were created out of 54 principles and rules from seven authors. Twelve keywords appeared only for one author, while four keywords appeared for two authors. The main keyword was selected as a word that had been stated by three and more authors in their principles. The main resulting keywords are stated in Table 4.

\subsection{Design analysis of motivation principles}

Five keywords were chosen based on the outputs of the content analysis, which were developed into general motivation principles. In order to prepare the general principles, motivation principles, rules and strategies were used, which were obtained from the content analysis and literature review.

- Principle 1 - Keyword Positive, inspiring leader

If a manager wants to motivate subordinates, he/she has to inspire others with all his/her actions. He/she has to be self-motivated but he/she cannot prefer his/her interests. It is necessary to have a certain level of confidence, enthusiasm and optimism and create attractive work conditions that will inspire other subordinates.

- Principle 2 - Keyword Care for employees

Every individual should be treated as though he/she is a celebrity. The manager should encourage his/her subordinates in their work, develop their skills and knowledge and express their confidence. A manager has to listen to impulses from subordinates, be ready to offer a helping hand by solving problems and encourage them to go in the right direction. A good manager shapes and builds formal and informal relationships between subordinates and provides all individuals the same conditions. He/she takes care of the quality of the relationship between manager and subordinate.

- Principle 3 - Keyword Creating and sharing goals, tasks and strategies

The manager should develop and share vision. He/she should focus on challenging but realistic and useful goals while setting. It is necessary to discuss objectives and tasks with subordinates. If possible, try to make subordinates identify with the objectives, because internal commitment leads to stronger motivation. The manager should also be focused on the quality of the fulfilled goals more than on the quantity of them.

\section{- Principle 4-Keyword Open communication}

Communication must be clear, transparent and without ironic comments and hidden allusions. Everyone should be able to engage in communication in the workplace.

- Principle 5 - Keyword Praise, recognition and appreciation

It is necessary to praise subordinates regularly for their performance and be sensitive to each contribution. Workers should be appreciated publicly. Praise has a specific character: it is addressed and informal. It is good to celebrate and share success together.

\subsection{Factor analysis}

The motivation principles that influence employee turnover were compiled through a document analysis and then a factor analysis was used to verify the resulting keywords and principles. Based on the literature review, the determinants (statements used by respondents to characterise the main reasons for leaving) of employee turnover were deduced. In two successive surveys, 29 determinants were used to describe the causes of employee turnover. A short description and explanation of the abbreviations of the determinants used in the survey to support analysis are shown in Table 5.

Analysis was carried out by using a correlation matrix, which showed the relations between determinants. Regarding overall weak to moderate dependences between determinants, which were constructed as independent for the survey because of their clear use for the construct, were not expected to find statistically significant factors. However, the correlation of determinants used for the factor analysis was strong enough (between 0.2 and 0.5) to give significant results by using the Varimax rotation method. As shown in Tables 6, 7 and 8, the factor analysis showed 13 statistically significant factors. To separate the final amount of output factors, the Kaiser-Guttman rule was employed. Such factors whose variance was above 1 were used for further analysis. This value was chosen rationally because the explanatory factor must have at least an equal value to the original standardised determinant.

Such determinants (statements) were chosen as significant to create resulting factors whose values were 0.3 and higher (Anderson, 2009). All factors together explained $69 \%$ of the internal organisational reasons to leave the job position. Tables 7 and 8 show all the factors and their determinants. For an explanation of the abbreviations of determinants, see Table 5.

Factor 1 showed the relation between the private and work lives of respondents and excessive workload. This factor can be therefore explained as the 
emphasis of employees on work/life balance. The first factor is also found in the first place by the factor analysis as the most significant, which is proved by the highest variance of this factor (1.9222648). This is the highest variance above all factors found by the factor analysis. Overall, the variance of all factors fluctuated between values $\langle 1,2\rangle$, thus it is not possible to mark the first factor as strongly deviating from the rest of the factors. Overall, it is possible to conclude that the surveyed employees are aware of their private lives and that they know their value, sense and goals.

Table 4 Resulting keywords

\begin{tabular}{|l|c|c|}
\hline Rank & Keyword & Number of authors \\
\hline 1. & Positive, inspiring leader & 5 authors \\
\hline 2. & Care for employees & 5 authors \\
\hline 3. & Creating and sharing goals, tasks and strategies & 4 authors \\
\hline 4. & Open communication & 3 authors \\
\hline 5. & Praise, recognition and appreciation & 3 authors \\
\hline
\end{tabular}

Table 5 Description of the determinants and explanation of abbreviations

\begin{tabular}{|c|c|c|c|}
\hline Abbreviation & Description & Abbreviation & Description \\
\hline FLEXI & Lack of flexibility of employment & RECOG & Lack of recognition \\
\hline STABIL & Uncertain stability of job position & TRUST & Lack of trust in top management \\
\hline LOAD & Excessive workload & UNFAIR & Unfair payment practices \\
\hline SOURC & Lack of sources & \multirow{2}{*}{ FUTUR } & \multirow{2}{*}{ Uncertainty about the future of the company } \\
\hline BENEFI & Inadequate benefits & & \\
\hline CULTUR & Inconvenient corporate culture & GROW & Lack of interest in future growth \\
\hline QUALIT & Lack of focus on quality & EXPECT & Lack of clear expectations \\
\hline RENUM & Inadequate salary & FILLI & Uninteresting or unfulfilling job \\
\hline PRODU & Lack of focus on productivity & TRAVEL & Excessive travel requirements \\
\hline DISPROP & $\begin{array}{l}\text { Disproportion between remuneration and } \\
\text { performance }\end{array}$ & COLLEA & Negative relationships with colleague(s) \\
\hline HONEST & Lack of honesty, ethics and integrity & TEAM & Lack of teamwork among employees \\
\hline COMMU & Lack of open communication & TREAT & Unfair treatment \\
\hline FEEDB & Lack of feedback & IDEAS & Lack of support of new ideas \\
\hline PODPOR & Lack of support of inputs and new ideas & PRIVAT & Imbalance between work and private life \\
\hline EDUCA & Lack of possibilities for education and growth & SUPER & Negative relationships with the supervisor(s) \\
\hline
\end{tabular}

Table 6 Variance explained by factors

\begin{tabular}{|l|c|c|c|}
\hline Factor & Variance & \% variance & Cumulative \% \\
\hline Factor 1 & 1.9222648 & 6.865231 & 13.52865231 \\
\hline Factor 2 & 1.8657445 & 6.663373 & 19.45554 \\
\hline Factor 3 & 1.6595419 & 5.926935 & 25.07316 \\
\hline Factor 4 & 1.5729333 & 5.617619 & 30.68732 \\
\hline Factor 5 & 1.5719660 & 5.614164 & 36.12627 \\
\hline Factor 6 & 1.5229047 & 5.438945 & 41.15542 \\
\hline Factor 7 & 1.4081631 & 5.029154 & 46.05930 \\
\hline Factor 8 & 1.3730865 & 4.903880 & 50.90122 \\
\hline Factor 9 & 1.3557379 & 4.841921 & 55.60171 \\
\hline Factor 10 & 1.3161358 & 4.700485 & 60.23793 \\
\hline Factor 11 & 1.2981427 & 4.636224 & 64.81549 \\
\hline Factor 12 & 1.2817171 & 4.577561 & 69.35751 \\
\hline Factor 13 & 1.2717636 & 4.542013 & \\
\hline
\end{tabular}


The determinants of factor 2 are connected with remuneration. The Varimax method showed dependence between the determinants Inadequate salary and Disproportion between remuneration and performance. The results indicate that employees who are dissatisfied with salaries are also dissatisfied with the evaluation of their performance. Such knowledge shows causality between the amount of remuneration and performance. Employees are aware of their performance and they realistically expect remuneration equal to performance. Their requirement seems to be legitimate. The analysis showed that sampled employees think about leaving the organisation if their performance and effort are underestimated.

Factor 3 showed an inconvenient corporate culture in the sense of minimum support of initiatives and new ideas. The results of the factor analysis chosen for factor number 3 were the determinants Inconvenient corporate culture and Lack of support of new ideas. These point out a rigid corporate culture. The surveyed employees feel disaffected because it is not possible to express their own initiatives to improve organisational practices and their own work. Sometimes, there is such a chance, but nobody reads or listens to those comments, nor develops or implements them. Organisational praxis thus should focus on strengthening the identification of good ideas of changes that come straight from the workflow. Employees know their routines the best of all and their improvements would make the whole organisation more effective. The disregard of such initiatives by an organisation leads to the resignation of employees who feel bound by organisational rules and practices, which are too long and inappropriate. Even a little change would solve the situation but if there is no chance to change, employees leave such an environment.

The fourth factor showed the connections between Lack of feedback, Lack of honesty, ethics and integrity in the organisation and Lack of focus on quality. It is possible to name this factor as economic responsibility, because organisations in this case follow only

Table 7 Resultant factors according to the Varimax method - part 1

\begin{tabular}{|l|c|c|c|c|c|c|c|}
\hline & Factor 1 & Factor 2 & Factor 3 & Factor 4 & Factor 5 & Factor 6 & Factor 7 \\
\hline PRIVAT & 0.568 & 0.165 & -0.442 & -0.053 & -0.019 & 0.090 & 0.117 \\
\hline LOAD & 0.933 & 0.018 & 0.063 & -0.125 & 0.039 & -0.028 & -0.103 \\
\hline RENUM & -0.068 & 0.879 & -0.085 & 0.047 & -0.082 & -0.075 & -0.064 \\
\hline DISPRO & 0.104 & 0.765 & -0.098 & -0.110 & 0.127 & 0.088 & 0.065 \\
\hline CULTUR & 0.031 & -0.119 & 0.904 & 0.117 & -0.007 & 0.002 & 0.159 \\
\hline IDEAS & -0.279 & -0.029 & 0.501 & 0.108 & -0.032 & 0.235 & 0.464 \\
\hline FEEDB & -0.101 & -0.016 & 0.125 & 0.883 & 0.071 & 0.027 & 0.017 \\
\hline HONEST & -0.115 & -0.119 & 0.030 & 0.446 & 0.597 & 0.352 & -0.053 \\
\hline QUALIT & -0.250 & -0.086 & 0.063 & 0.477 & -0.134 & 0.082 & 0.359 \\
\hline TREAT & 0.088 & 0.114 & -0.023 & -0.022 & 0.855 & 0.161 & 0.153 \\
\hline RECOG & 0.041 & 0.045 & -0.009 & 0.131 & 0.308 & 0.833 & 0.131 \\
\hline EXPECT & -0.128 & -0.015 & 0.206 & -0.269 & 0.025 & 0.533 & -0.029 \\
\hline TRUST & -0.011 & 0.030 & 0.150 & 0.018 & 0.123 & 0.057 & 0.855 \\
\hline
\end{tabular}

Table 8 Resultant factors according to the Varimax method - part 2

\begin{tabular}{|l|c|c|c|c|c|c|}
\hline & Factor 8 & Factor 9 & Factor 10 & Factor 11 & Factor 12 & Factor 13 \\
\hline GROW & 0.870 & -0.126 & -0.141 & 0.138 & -0.027 & -0.081 \\
\hline PRODU & 0.334 & -0.208 & -0.223 & -0.188 & 0.480 & -0.062 \\
\hline IDEAS & 0.312 & -0.060 & -0.066 & -0.200 & -0.055 & -0.112 \\
\hline EXPECT & -0.029 & 0.411 & 0.356 & -0.062 & -0.084 & -0.138 \\
\hline COLLE & -0.109 & 0.843 & 0.042 & -0.139 & 0.010 & -0.096 \\
\hline SOURC & -0.135 & 0.072 & 0.832 & 0.066 & -0.216 & 0.171 \\
\hline UNFAIR & -0.302 & -0.223 & 0.129 & 0.310 & -0.043 & 0.388 \\
\hline FUTUR & 0.123 & -0.164 & 0.064 & 0.854 & -0.053 & 0.132 \\
\hline SUPER & -0.090 & 0.052 & -0.237 & -0.010 & 0.800 & -0.087 \\
\hline STABIL & -0.072 & -0.110 & 0.170 & 0.129 & -0.087 & 0.827 \\
\hline
\end{tabular}


their own interests (particularly finance, i.e. economic), regardless of the impact on surroundings and stakeholders. Employees are also stakeholders. Employees can see the inappropriate practices of an organisation and thus are not satisfied with preferred values that are characterised by a lack of interest in subordinates in the sense of a lack of feedback, no information about tasks, projects and the whole organisational development, unconcern about ethical issues, and no integrity of the organisation and its departments. Workers (managers and employees) are not honest with each other, information is not shared and quality is not supported. Such an output notes organisations to be aware that employees with ethical values cannot tolerate such organisational activities because it is contrary to their beliefs. Employees are unwilling to stay in organisations when they do not support and believe in the quality of their own products and cannot get information about their own work and organisation.

Factor 5 follows the previous findings. The factor combines the determinants Lack of honesty, ethics and integrity, Unfair treatment and Lack of recognition. The combination of these determinants leads to the perception that employees are managed as machines, without any interest in their feelings, needs, fair treatment or appreciation of their work. Employees showed interest in their future growth and the growth of the organisation as well as the ethical and appropriate behaviour of workers inside the organisation with each other and other stakeholders. Surveyed employees consider their jobs not just as a duty, but also they see them as a possibility to grow and they want to feel proud of their organisations and of the positions they hold in the organisation.

Factor 6 also shows inappropriate practices inside the organisation as a reason for employees leaving their jobs. The combination of determinants Lack of honesty, ethics and integrity, Lack of recognition and Lack of clear expectations leads to disproportions between the expected and real situations inside the organisation by employees. Employees once again demonstrated their sense of ethics and efforts to initiate during their work. Effort or initiative is unfortunately not expected nor supported by managers and organisations.

Factor 7 combines the Disaffection of employees with Lack of support of new ideas, Lack of focus on quality and Lack of trust in top management. Such a combination indicates an unclear or insufficient vision or strategy of the organisation perceived by employees. Subordinates do not trust in management and company leaders and their own efforts to change inadequate processes are not supported or implemented. Employees see a problem in quality and they are not convinced of the suitability of products or services provided to customers. Effort to change such a situation is ignored by company management and therefore employees decide to leave the organisation, which do not have a clear and long-term sustainable vision and strategy.

Factor 8 showed that employees focus on innovation and their own growth. The combination of the determinants Lack of interest in future growth, Lack of focus on productivity and Lack of support of new ideas tend to realise that employees would like to use their knowledge, abilities and experiences. Their organisations do not let them develop their abilities. Organisations seem to be rigid with fixed processes and procedures with no place for innovation, productivity and efficiency. Such incompatibility with employees' initiatives indeed leads to turnover, because employees decide to use their talents somewhere else.

The ninth factor is quite different from the others. It combines the determinants Lack of clear expectations and Negative relationship with a colleague(s). The combination of those determinants shows problematic relationships within hierarchic levels and thus the inappropriate structure of teams, because the expectations of each member of the team are completely different. Therefore, it is necessary to pay attention to the composition of teams from day one. To create smoothly working teams, employees need to be recruited into posts and positions in order to comply with colleagues and the collective. If there is no such compliance, employees will not stay any longer than necessary and the organisation records a higher turnover rate and its costs in vain.

The outputs of factor 10 showed lack of resources or fight for resources in organisations. The combination of the determinants Lack of clear expectations and Lack of sources leads to reflection on how organisations inform employees about the requirements and possibilities of job positions during recruitment interviews. This seems to be inadequate, because employees entering their new job positions have completely different ideas about how and what kinds of tolls and sources they will work with. If they do not have access to the necessary sources, it leads to conflict, and if such conflict is never solved, employees leave.

The 11th factor showed the legitimate uncertainty of employees regarding the futures of their organisations. The determinants Unfair payment practices and Uncertainty about the future of the company clearly indicate the reason for these concerns. If employees feel threatened by illegal acts of the organisation, it threatens their own futures. Many surveyed employees perceive such a feeling so intensively that it forces 
them to leave the job position before the negative impact of the legal disputes will come true. The significance of this statement is proved by of the other analyses, which stated the same thing. That indicates more often the appearance of this situation in the Czech Republic.

Factor 12 should be called Conservative supervisor, because it connects Lack of focus on productivity and Negative relationship with the supervisor(s). It appears that employees often leave job positions because of problematic relationships with their managers. Such problems are caused by negative or lax approaches to the efforts of employees to increase productivity or to implement new processes. This factor explains the possible reasons for problems between hierarchic levels in the organisation. This threatens the efficiency of the organisation because suggested improvements by employee will never be implemented; thus, the organisation will lose employees and that generates further costs. There arises another reason to monitor the turnover rate in departments and teams subordinated to one supervisor, because inside a small group it is easier to show causes of turnover and then to start a process of lowering employee turnover.
The same as factor 11, factor 13 also explains the reasons for leaving the organisation as a reduction in concerns about future job positions. The combination of the determinants Unfair payment practices and Uncertain stability of employment clearly indicates the cause of the problem. Employees feel threatened in their job positions because they perceive uncertainty in an organisation that used unfair payment practices to customers, partners and suppliers. Table 9 shows a summary of the names of all factors revealed by the factor analysis.

\section{Discussion}

The comparison of the results of both analyses is shown in Table 10. Those factors found by the factor analysis support the identified motivation principles. Usually, one motivation principle is supported by two or three factors revealed by the factor analysis. The factors resulting from the factor analysis are (because of concrete names and determinants) more specific and exactly targeted to the in-depth issues inside organisations. Therefore, we may conclude that the organisation should focus on motivation increases

Table 9 Names of factors

\begin{tabular}{|l|c|l|c|}
\hline Factor & Name & Factor & Name \\
\hline 1 & Life (im)balance & 8 & Ignore of innovation \\
\hline 2 & Fair remuneration & 9 & Structure of teams \\
\hline 3 & Rigid culture & 10 & Fight for resources \\
\hline 4 & Economic responsibility & 11 & Law avoidance \\
\hline 5 & Human resource management & 12 & Conservative supervisor \\
\hline 6 & Expected position & 13 & Threatened future \\
\hline 7 & Vision of organisation & &
\end{tabular}

Table 10 Comparison of analyses

\begin{tabular}{|l|l|}
\hline Content analysis & Factor analysis \\
\hline Positive, inspiring leader & Ignore of innovation \\
\cline { 2 - 2 } & Conservative supervisor \\
\hline Care for employees & Life (im)balance \\
\cline { 2 - 2 } & Rigid culture \\
\cline { 2 - 2 } & Human resource management \\
\hline Creating and sharing of goals, tasks and strategies & Economic responsibility \\
\cline { 2 - 2 } & Vision of organisation \\
\cline { 2 - 2 } & Fight for resources \\
\hline Open communication & Structure of teams \\
\cline { 2 - 2 } & Law avoidance \\
\hline Praise, recognition, appreciation & Threatened future \\
\cline { 2 - 2 } & Fair remuneration \\
\cline { 2 - 2 } & Expected position \\
\hline
\end{tabular}


using the resulting motivation principles to eliminate a negative turnover rate.

The left side of Table 10 contains the results of the content analysis of motivation principles; the right side of the table shows the summary of those factors that affect motivation, namely cause demotivation and employee turnover. The names of factors are often inverse compared with the motivation factors. This is because of the primary description of factors as causes of turnover. Therefore, they are similar to factors of demotivation. The exact description and structure of factors is shown in the previous section.

All the factors revealed by the factor analysis were assigned to motivation principles shown by the content analysis, as stated in Table 10. Principles are wide because of the selected keywords. Thus, it is possible to classify the factors from the factor analysis under principles as their criteria. In conclusion, it is possible to summarise that even the actual assignment of factors to resulting keywords from the content analysis confirms their explanatory power and validity.

Positive, inspiring leader is supported by factors that include the demotivation of employees caused by the ignorance of their initiatives by supervisors, veto of any improvements and ideas and impossibility to express freely their suggestions and opinions. Supervisors who overlook productivity and growth and who poorly communicate with their subordinates cause the aversion of employees and demotivation. Such practices lead to negative relationships with supervisors and subsequent disagreements, which are caused by negative or lax approaches to the efforts of employees to increase productivity or implement new procedures.

Care for employees is also one of the main motivation principles because it is supported by factors whose cumulative meaning condemns imbalance between work and private life and work overload together with insufficient corporate culture. There is minimum support of initiatives and new ideas by employees who feel locked inside long and inconvenient organisational procedures when they know that small changes would solve the whole problematic situation. Employees are also motivated by organisational care about good feelings about their job positions in the organisation. If the organisation does not care about ethical principles, equal treatment, approach and work appreciation, employees feel demotivated by a lack of care and interest in their work. Thus, the tendency to leave the job position occurs.

Creating and sharing goals, tasks and strategies is supported by the factor analysis, which found that employees are demotivated if an organisation shows a lack of feedback, integrity, honesty and ethical communication, a lack of future goals and strategies, and a lack of focus on quality and therefore a loss of customers. This leads to threaten the whole organisation. A lack of quality, sources, support of innovation and clear expectations finally leads to distrust in the organisation.

Open communication is a very important motivation principle according to the surveyed employees. The results of the factor analysis showed problems in communication that lead in the end to employee turnover. If employees do not have information about payment practices or if they consider them to be unfair, and in the organisation if nobody sufficiently explains the nature of the real situation, a tendency to leave appears. This is because employees feel uncertainty about the company's future and their own job positions. Another problematic factor of communication is improperly assembled and trained teams. This leads to problematic co-working of colleagues who refuse to talk to each other and thus work together. This significantly negatively influences the outputs and efficiency of an organisation. This factor also indicated disagreement with expectations. This indicates that employees are not clearly informed about job positions and their requirements during recruitment. It is necessary for organisations to focus on open and clear communication regarding the requirements and possibilities of offered job positions including information about future team and colleagues where the potential employee will work. Otherwise, there is a real and quite high probability that he/she will leave soon because of demotivation.

Praise, recognition and appreciation are often overlooked and unrecognised motivation principles by managers. Employees are usually dissatisfied (according to the results of the factor analysis) with nonprestigious employment where unfair payment practices play a part and this is perceived by stakeholders and the public. Thus, the social statute and position of employees in this kind of organisation decrease. Employees do not want to commit such a situation and rather choose to leave and change their employment. Likewise, employees want to feel recognised, they require honesty in acting and behaviour, which belongs to their position and expectations connected to their status. Together with appreciation is connected remuneration. Salary and benefits are strong motivation factors for employees. Although it is not the only motivational factor, it is still very important for employees.

Employees regard the outputs of analyses the most demotivated by inadequate salary and by the connection to the evaluation of performance. If employees do not feel they are adequately awarded for their expended effort and drive or they perceive disparity in the evaluation compared with other employees, demotiva- 
tion is so strong that it leads to a decision whether to leave or stay in the organisation.

\section{Conclusions}

A manager is defined as someone who achieves the goals of the organisation through subordinates. It is necessary to motivate employees, encourage them and move them in the desired direction in order to achieve these goals. The authors of the paper incline to the attitude that the manager's role is to support and stimulate their subordinates despite the ambiguity of the work motivation effects. Even though motivation does not work as desired, if the manager does not treat employees with respect and he/she does not appreciate contributions and does not communicate with them, employees will not be satisfied. If motivation is lost, performance is degraded and this leads to mental problems, absenteeism and turnover. Motivation principles are unable to affect the whole motivation role. Motivation principles, which were introduced by authors in a content analysis, are only guidelines on how to progress according to the motivation role. No motivation principle can be efficient if the stimulus is not in harmony with the internal motives of subordinates, motivation statements of the organisation and managers' actions.

This research conducted on a random sample of respondents confirmed the theoretical bases regarding the factors affecting employee turnover. The factor analysis identified 13 significant factors leading to the decision of employees to leave their job positions in the organisation. Correlation analysis indicated strong strict dependence between the disaffection of employees with the listed factors and leaving job position.

The satisfaction of employees in the organisation is connected with internal organisational practices and personal preferences. The resulting factors show a connectedness of turnover and perception of equal and fair treatment, whether this concerns fair and adequate remuneration, distribution of tasks and projects, work methods, promotion or equal access to resources. A perceived imbalance between colleagues at the same hierarchical level in the stated factors often leads to tendencies to leave the employment. Employee turnover is also influenced by unfair internal organisational practices. The surveyed employees rather leave their job positions ahead of time than view the lack of ethical action by the firm, machinations with finances and an unclear vision and future.

Regarding the multiple appearances of similar factors, it is not possible to consider this result as accidental; it is necessary to pay attention to this phenomenon. Often, this perception is invoked by employees as a lack of communication and information. Employ- ees automatically predict the worst scenario. Clear communication and an explanation of strategy and the basic points of the planned future growth of the organisation completely change employees' views of the whole situation and also lead to an immediate lowering of employee turnover.

In conclusion, to lower employee turnover, it is suggested to:

- Encourage independence, work on career planning, employee education, learning and development, innovations,

- Communicate openly, honestly and often, share information,

- Ask and listen and then lower the difference between the desired and real situations,

- Encourage employees to increase their feelings of importance, satisfaction and usefulness for the organisation,

- Appreciate employees' work and performance and secure their need for future security and recognition,

- Compensate and remunerate equally but in the context of performance,

- Encourage friendship and good relationships and work on organisational climate and open culture,

- Share the vision of the management team and allow the strategy to spread to all parts of the organisation,

- Focus on recruitment and people's expectations, hire the right people in the right places and treat them with respect.

The key point for reducing turnover is to change the style of working with employees by encouraging independence, career planning, open communication and sharing information. As human resource management theory states, it is necessary to take into account the needs of employees at different levels of development. The needs that are often overlooked and problematic are those of solidarity, friendship, safety and security, fulfilment, recognition by a team and selffulfilment. The perceived difference between the desired and real situations causes dissatisfaction and employees tend to leave their jobs. Employees need to be encouraged to perform their tasks in order to increase their feelings of importance, satisfaction and usefulness for the organisation and in particular to maintain and increase the overall performance of the organisation. It is obvious that employees who are not encouraged do not have enough information, while those that are criticised are almost certain to leave the organisation. 


\section{References}

ANDERSON, V. (2009). Research Methods in Human Resource Management. London: Chartered Institute of Personnel Development.

ARMSTRONG, M. (2009). Armstrong's handbook of human resource management practice. London: Kogan Page.

BĚLOHLÁVEK, F. (2008). Jak vést a motivovat lidi. Brno: Computer Press.

BRANHAM, L. (2005). The 7 hidden reasons employees leave. New York: AMACOM.

CRAINER, S. (2004). Handbook of Management. London: Pearson Education.

DAIGELER, T. (2008). Vedení lidí v kostce. Praha: Grada Publishing.

DECI, E., RYAN, R.M. (2008). Facilitating optimal motivation and psychological Well-Being across life's domains. Canadian Psychology 49(1): 14-34. http://dx.doi.org/10.1037/0708-5591.49.1.14

DEL VECCHIO, S., WAGNER, J. (2011). Motivation and monetary incentives: A closer look. Journal of Management and Marketing Research 7(1): 1-13.

DEIBLOVÁ, M. (2005). Motivace jako nástroj ř́zení. Praha: Linde.

DISMAN, M. (2008). Jak se vyrábi sociologická znalost. Praha: Karolinum.

HACKMAN, J.R., OLDHAM, G.R. (1980). Work redesign and motivation. Professional Psychology 11(3): 445-455. http://dx.doi.org/10.1037//0735$\underline{7028.11 .3 .445}$

HANSEN, B., WADE, G., HAMEL, T. (2003). Successful coaches' views on motivation and motivational strategies. Journal of Psychical Education, Recreation and Dance 74(6): 44-48.

HAYES, N. (1998). Základy sociální psychologie. Praha: Portál.

JENKINS, A.K. (2009). Keeping the talent: understanding the needs of engineering and scientists in the defense acquisition workforce. Defense A $R$ Journal 1(4): 164-170.

KATCHER, B.L., SNYDER, A. (2007). 30 Reasons Employees hate their Managers. New York: AMACOM.

KOCIANOVÁ, R. (2010). Personální činnosti a metody personální práce. Praha: Grada.

KOLMAN, L. (2003). Kapitoly z psychologie pro ekonomy - II. část. Praha: Credit.

LINHART, Z. (2003). Marketing. Praha: Credit.

MASLOW, A. (1943). A theory of human motivation. Psychological Review 50(4): 370-396.

http://dx.doi.org/10.1037/h0054346
MEYER, J.P., ALLEN, N.J. (1991). A threecomponent conceptualization of organizational commitment. Human Resource Management Review 1(1): 61-89. http://dx.doi.org/10.1016/10534822(91)90011-Z

MIKULÁŠTÍK, M. (2007). Manažerská psychologie. Praha: Grada Publishing.

MINTZBERG, H. (2006). Le manager au quotidien: Les dix rôles du cadre. Paris: Editions d'Organisation.

NIERMEYER, R., SEYFFERT, M. (2007). Motivation. München: Haufe.

PLAMÍNEK, J. (2010). Vzdělávání dospělých. Praha: Grada Publishing.

RAMLALL, S. (2004). A review of employee motivation theories and their implications for employee retention within organizations. The Journal of American Academy of Business 5(1): 52-63.

STÝBLO, J. (2008). Management a lidé ve firmě. Praha: EUPRESS.

ŠULĚ̌, O. (2008). 5 roli manažera a jak je profesionálně zvládnout. Brno: Computer Press.

ŠULĚ̌, O. (2002). Zvládáte své manažerské role? Brno: Computer Press.

WONG-ON-WIN, B., GUO, L., LUI, G. (2010). Intrinsic and extrinsic motivation and participation in budgeting: Antecedents and consequences. American accounting association 22(2): 133-153. http://dx.doi.org/10.2308/bria.2010.22.2.133

\section{Additional sources}

BOWES, B.J. (2010). A Competitive Employee Market Compels Companies to Manage High Turnover. [Online], [cit. 30. 06. 2010]. Legacy Bowes Group. Available at: <http://legacybowesgroup.com/compo nent/content/article/43-retention/183-a-competitiveemployee-market-compels-companies-to-managehigh-turnover.html $>$.

ERTL, J. (2005). Fluktuace - diagnóza a léčba. [Online]. [cit. 28. 03. 2010]. Person all consulting. Available at: <http://www.personall.cz/Fluktuace I.html>.

GORDON, J. (2010). Why your Company Needs Motivation More than ever... and Six Ways you can Share it. [Online], [cit. 22. 05. 2011]. Available at: <http://newsblaze.com/story/2010100 7164457zzzz.nb/topstory.html>.

LA BROSSE, M. (2010). Burned Up over Burnout? [Online], [cit. 02. 07. 2011]. Available at: $<$ http://www.productionmachining.com/columns/burn ed-up-over-burnout>.

PASS, S. (2005). On the line. People Management Magazine. [Online], [cit. 10. 05. 2013]. Available at: 
$<\mathrm{http}: / /$ www.peoplemanagement.co.uk/pm/articles/20 05/09/ontheline.htm>.

REIß, Ch. (2008). Fluktuation. [Online], [cit. 30. 03. 2010]. Available at: <http://www.personaler-on line.de/ypo3/nc/personalthemen/suche-in-artikeln/ detailansicht/artikel/fluktuation.html $>$.

VAITKUVIENÉ, L., BALVOČIUTÉ, R., STOŠKUS, S. (2010). The Comparitive Analysis of Employee Motivation Tooles: The Case of Lithuanian and Swedish Manufacturing Companies. Management of Organizations: Systematic Research. [Online], [cit. 05. 02. 2012]. Available at: <http://www.zaraiv.com/ From\%20Zara/July-10/19-07/1/J007083E/1UZD20100601-pdf/1UZD06012010007.pdf>.

ZAHORSKY, D. (2010). Fighting Employee Turnover Costs: Reduce Employee Turnover. [Online], [cit. 02. 07. 2011]. Available at: <http://sbinformation.about. com/od/hiringfiring/a/reduceturnover.htm $>$. 